\title{
PEMBELAJARAN DISKURSUS MULTI REPRESENTASI (DMR) DENGAN SPARKOL VIDEOSCRIBE UNTUK MENINGKATKAN KEMAMPUAN REPRESENTASI MATEMATIS
}

\author{
Siti Rukiyah, Rany Widiyastuti, dan Andi Thahir \\ Universitas Islam Negeri Raden Intan Lampung \\ e-mail: sitirukiyah@gmail.com
}

\begin{abstract}
Abstrak
Tujuan penelitian ini adalah untuk menguji dan mendeskripsikan pengaruh model pembelajaran Diskursus Multy Reprecentacy berbatuan Sparkol videoscribe terhadap kemampuan representasi matematis peserta didik. Metode yang digunakan adalah kuasi eksperimen menggunakan 3 kelompok yaitu kelas eksperimen 1 menggunakan model pembelajaran Diskursus Multy Representasi berbantuan sparkol videoscribe, kelas eksperimen 2 yang menggunakan model pembelajaran Diskursus Multy Representasi, dan kelas eksperimen 3 sebagai kelas kontrol menggunakan model pembelajaran konvensional yang masing-masing dipilih secara acak. Instrumen yang digunakan dalam penelitian ini adalah tes kemampuan representasi matematis yang meliputi 3 aspek, yaitu representasi visual, simbolik, dan verbal. Teknik analisis data menggunakan komparasi secara statistik. Hasil dari penelitian ini menunjukkan bahwa model pembelajaran DMR berbantuan sparkol videoscribe sama baiknya dengan model pembelajaran DMR terhadap kemampuan representasi matematis. Model pembelajaran DMR lebih baik dari model pembelajaran konvenional terhadap kemampuan representasi matematis.
\end{abstract}

Kata Kunci: Diskursus Multy Reprecentacy, Kemampuan Representasi Matematis, Sparkol Videoscribe

\begin{abstract}
This study intended to examine and describe the effect of the Discourse Multy Representation learning model assisted by Sparkol Videoscribe on the mathematical representation abilities of the students. The method used is quasi-experimental using 3 groups with the first experimental group using the Discourse Multy Representation learning model assisted by sparkol videoscribe, the second experimental group using the Multy Representation Discourse learning model, and the third experimental group as the control class using the conventional learning model, each of which is selected randomly. The instrument used in this study was a mathematical representation ability test which included 3 aspects, namely visual, symbolic, and verbal representations. Data analysis techniques used statistical comparisons. The results of this study indicate that the DMR learning model assisted by sparkol videoscribe is as good as the DMR learning model on the ability of mathematical representation. DMR learning model is better than the conventional learning model for mathematical representation ability.
\end{abstract}

Keywords: Multy Reprecentacy Discourse, Mathematical Representation Ability, Sparkol Videoscribe 


\section{PENDAHULUAN}

National Council of Teachers of Mathematics (NCTM) menetapkan lima standar kemampuan matematis yang harus dimiliki oleh peserta didik, yaitu kemampuan pemecahan masalah, kemampuan komunikasi, kemampuan koneksi, kemampuan penalaran dan kemampuan representasi (Hutagaol, 2013; Effendi 2012). Representasi merupakan suatu konfigurasi yang dapat menggambarkan, melambangkan, atau mewakili sesuatu dalam suatu cara tertentu (Bani, 2016; Yekti, 2018; Zulfikar, 2019; Lahope, Tulandi, \& Mongan, 2020). Kemampuan representasi matematis digunakan untuk membantu peserta didik dalam berpikir matematis dan mengkomunikasikan ide-idenya (Umar, 2012; Hutagaol, 2013; Handayani, 2015; Nadia \& Isnarto, 2017). Terutama dalam berkomunikasi, kemampuan representasi matematis sangat penting antara lain representasi eksternal berupa gambar (model), simbol, grafik, maupun objek fisik (Saputri \& Sari, 2017; Syafri, 2017; Rahmawati, 2020). Kemampuan representasi matematis juga dapat membantu peserta didik dalam pemecahan masalah matematika (Sabirin, 2014; Nahdi, 2017; Bagus, 2018). Kemampuan representasi matematis merupakan hal yang selalu muncul ketika seseorang mempelajari matematika (Sahara, 2017; Nursahara, 2017; Fitrianingrum \& Basir, 2020). Berdasarkan uraian tersebut, kemampuan representasi matematis merupakan kemampuan menyajikan kembali notasi, simbol, tabel, grafik, diagram, persamaan matematis kedalam bentuk lain yang diukur dengan indikator kemampuan representasi matematis. Kemampuan ini penting dimiliki peserta didik dan perlu diberdayakan dalam pembelajaran matematika. Tabel 1 menunjukkan indikator kemampuan representasi matematis menurut Syafri (2017); Fitri, Munzir, \& Duskri, (2017).

Tabel 1. Indikator Kemampuan Representasi Matematis

\begin{tabular}{|c|c|}
\hline Representasi & Bentuk-bentuk Operasional \\
\hline $\begin{array}{l}\text { Visual } \\
\text { (diagram, tabel, atau grafik) }\end{array}$ & $\begin{array}{l}\text { 1. Menyajikan data atau informasi kembali dari representasi } \\
\text { diagram, grafik, atau tabel } \\
\text { 2. Menggunakan representasi visual untuk menyelesaikan } \\
\text { masalah }\end{array}$ \\
\hline Gambar & $\begin{array}{l}\text { 1. Membuat gambar pola geometri } \\
\text { 2. Membuat gambar untuk mengklarifikasi masalah dan } \\
\text { memfasilitasi solusinya }\end{array}$ \\
\hline Simbolik & $\begin{array}{l}\text { 1. Menyelesaikan masalah dengan melibatkan ekspresi } \\
\text { matematis }\end{array}$ \\
\hline $\begin{array}{l}\text { Verbal } \\
\text { (katakata/teks tertulis) }\end{array}$ & $\begin{array}{l}\text { 1. Membuat situasi masalah berdasarkan data atau representasi } \\
\text { yang disediakan } \\
\text { 2. Menuliskan interpretasi dari suatu } \\
\text { representasi } \\
\text { 3. Menuliskan langkah-langkah untuk menyelesaikan masalah } \\
\text { matematika dengan kata-kata } \\
\text { 4. Menyusun cerita yang sesuai dengan representasi yang } \\
\text { disajikan } \\
\text { 5. Menjawab pertanyaan menggunakan kata-kata atau teks } \\
\text { tertulis }\end{array}$ \\
\hline
\end{tabular}


Salah satu cara yang dapat dilakukan agar peserta didik menguasai pelajaran sesuai dengan target yang akan dicapai dalam kurikulum adalah memilih model pembelajaran yang tepat. Penerapan model yang tepat dapat berpengaruh terhadap keberhasilan dalam proses pembelajaran (Kristin \& Rahayu 2016; Sugiana et al., 2017; Mulyono, 2018; Yuliarti, 2018). Salah satu model pembelajaran yang dapat diterapkan adalah model pembelajaran Diskursus Multy Representasi. Model pembelajaran Diskursus Multy Reprecentacy (DMR) bertujuan untuk membentuk karakter peserta didik dengan menggunakan berbagai representasi dalam proses pembelajarannya, sehingga tepat digunakan dalam proses pembelajaran (Tristiyanti and Afriansyah 2017; Herman, Artinah, and Usdiyana 2017).

Model pembelajaran kooperatif tipe Diskursus Multy Representasi yang selanjutnya disingkat DMR merupakan bagian dari pembelajaran kooperatif(Tristiyanti and Afriansyah 2017). Menurut Slavin penggunaan pembelajaran kooperatif dapat meningkatkan prestasi belajar para peserta didik dan dapat mengembangkan hubungan antar kelompok, penerimaan terhadap teman sekelas yang lemah dalam bidang akademik, dan meningkatkan rasa percaya diri (Aulia, Zulhendra, \& Jaya 2014; Mulyono, 2018). Tujuannya model pembelajaran kooperatif yaitu untuk bekerja sama dengan peserta didik lainnya, membuat hubungan positif, melatih kepercayaan diri, dan meningkatkan kemampuan belajar dengan kegiatan kelompok(Rosita and Leonard 2015; Subakti 2010). Model pembelajaran DMR (Diskursus Multy Reprecantacy) adalah model yang mengajarkan proses pemecahan masalah dan mengembangkan keterampilan pemecahan masalah. Model pembelajaran kooperatif tipe DMR merupakan model pembelajaran yang menekankan belajar dalam kelompok heterogen saling membantu, kerja sama memecahkan masalah, menyatukan pikirantguna memperoleh keberhasilan yang optimal (Tristiyanti and Afriansyah 2017). Menurut Sahyudin tahapan-tahapan model pembelajaran DMR yaitu : "persiapan, pendahuluan, pengembangan, penerapan, dan penutup"(Rostika and Junita 2017).

Kelebihan dari Model Pembelajaran Diskursus Multy Representation (DMR) menurut Rostika dan Junita yaitu melatih peserta didik supaya mampu berinteraksi dan bekerjasama dengan teman kelompoknya dalam memecahkan suatu permasalahan, peserta didik akan lebih aktif dalam pembelajaran(Rostika and Junita 2017; Yandari and Nailah 2019), materi pembelajaran mudah dimengerti oleh peserta didik(Ulfah 2012; Situmorang 2014), pembelajaran lebih rileks dan menyenangkan dan terjadinya komunikasi yang baik antara guru dan peserta didik(Rostika and Junita 2017; Anggoro, Harmianto, and Yuwono 2018). Kekurangan dari model Diskursus Multy Representasi yaitu membutuhkan waktu yang cukup lama karena dalam kegiatan eksplorasi media peserta 
didik perlu adanya diskusi dan melakukan pencarian informasi dan Guru harus mempersiapkan media dan merencanakan pembelajaran dengan baik(Nurfaisah 2018).

Sparkol videoscribe adalah salah satu media pembelajaran berbentuk video animasi terdiri dari serangkaian gambar mati disusun menjadi satu video. Memiliki karakteristik yang unik, sparkol videoscribe mampu memberikan konten pembelajaran dengan menggabungkan gambar, suara, grafis serta desain menarik sehingga membuat peserta didik menikmati pembelajaran. Fungsi dari Sparkol videoscribe tidak terbatas sehingga dapat dinyatakan untuk menarik perhatian pengunjung blog dan website, untuk penawaran Afilasi, untuk mempromosikan jasa online dan offline dan untuk media pembelajaran.

Kenyataan di lapangan, kemampuan representasi matematis cenderung dikesampingkan oleh guru dalam proses pembelajaran matematika, seperti halnya yang terjadi di SMPN 3 Jati Agung. Berdasarkan hasil wawancara dengan beberapa peserta didik didapatkan informasi bahwa banyak peserta didik tidak menyukai pembelajaran matematika dan berasumsi bahwa matematika sulit untuk di pelajari. Peserta didik cenderung tidak dapat menjawab soal yang tidak sama dengan contoh yang diberikan oleh guru pada saat pembelajaran. Pada jawaban peserta didik hanya menempatkan angka yang dibutuhkan kedalam rumus serta untuk dapat meningkatkan pemahaman pola-pola matematika peserta didik memerlukan waktu serta bantuan untuk mengembangkan kemampuannya memahami pengetahuan baru. Berdsarkan permasalahan tersebut dapat disimpulkan bahwa kemampuan representasi matematis peserta didik kelas VII SMPN 3 Jati Agung masih rendah.

Penelitian sebelumnya banyak dilakukan seperti Tristiyanti \& Afriansyah (2017); Budarsini, Suarsana, \& Suparta (2018); Purwasih \& Bernad (2018); Ahmad, Loka \& Mutiah (2020) dimana DMR telah terbukti efektif dalam memberdayakan kemampuan representasi peserta didik dan juga hasil belajar lainnya seperti kemampuan komunikasi, pemecahan masalah hingga penguasaan konsep. Tapi ada yang berbeda dengan penelitian ini, yaitu menguji implementasi DMR berbatuan Sparkol Videoscribe, sehingga memberikan informasi baru tentang hasil dari implementasi DMR dan memberi kontribusi perkembangan ilmu pengetahuan, khususnya dalam ilmu pendidikan. Implementasi model Diskursus Multi Representasi (DMR) dengan Sparkol Videoscribe dapat dijadikan alternatif solusi untuk meningkatkan kemampuan representasi matematis peserta didik. Hasil penelitian ini mendiskripsikan pengaruh model pembelajaran DMR berbantuan Sparkol Videoscribe terhadap kemampuan representasi matematis peserta didik. 


\section{METODE}

Metode yang digunakan adalah kuasi eksperimen menggunakan 3 kelompok yaitu kelas eksperimen 1 menggunakan model pembelajaran Diskursus Multy Representasi berbantuan sparkol videoscribe, kelas eksperimen 2 yang menggunakan model pembelajaran Diskursus Multy Representasi, dan kelas eksperimen 3 sebagai kelas kontrol menggunakan model pembelajaran konvensional yang masing-masing dipilih secara acak. Instrumen yang digunakan dalam penelitian ini adalah tes kemampuan representasi matematis yang meliputi 3 aspek, yaitu representasi visual, simbolik, dan verbal. Teknik analisis data menggunakan komparasi secara statistik. Tabel 2 menunjukka desain penelitian.

Tabel 2. Desain Penelitian Faktorial 1 X 3

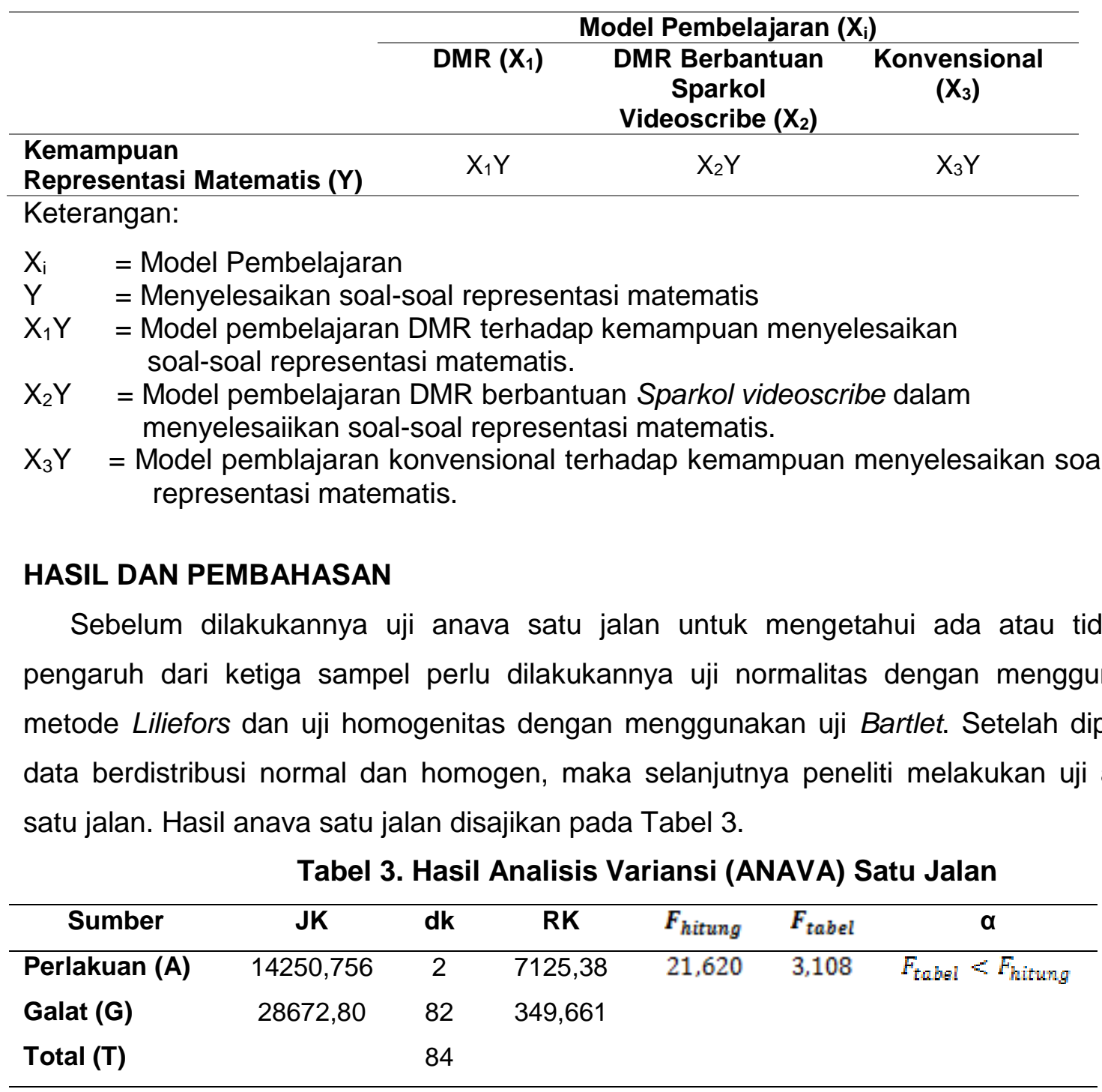

Dari perhitungan pengujian analisis data yang telah dilakukan diperoleh $F_{\text {hitung }}=21,620$ dan $F_{\text {tabel }}$ 3,108. Kemudian $F_{\text {hitung }}$ tersebut dibandingkan dengan $F_{\text {tabel }}$. Nilai 
$F_{\text {hitung }}>F_{\text {tabel }}$ maka $H_{0}$ ditolak artinya terdapat pengaruh model DMR berbantuan sparkol videoscribe terhadap kemampuan representasi matematis. Untuk melihat manakah model pembelajaran yang secara signifikan memberikan pengaruh yang berbeda terhadap kemampuan representasi matematis, maka dilakukan uji lanjut pasca anava.

Sebelum diakukan uji lanjut pasca anava dicari deskripsi data nilai tes dari masingmasing sampel. Deskripsi data nilai tes kemampuan representasi matematis peserta didik kelas eksperimen dan kelas kontrol ditunjukkan pada Tabel 4.

Tabel 4. Deskripsi Data Nilai Kemampuan Representasi matematis

\begin{tabular}{lcccccc}
\hline \multicolumn{1}{c}{ Kelas } & $X_{\max }$ & $\boldsymbol{X}_{\min }$ & \multicolumn{3}{c}{ Ukuran Tendensi Sentral } & \multirow{S}{*}{$\boldsymbol{S}$} \\
\cline { 4 - 6 } & & & $\bar{x}$ & $M_{e}$ & $M_{0}$ & \\
\hline Eksperimen 1 & 96 & 44 & 73,366 & 74 & 67 & 13.727 \\
Eksperimen 2 & 93 & 44 & 71,300 & 68.5 & 67 & 17.959 \\
Kontrol & 81 & 15 & 44,733 & 44 & 26 & 17.694 \\
\hline
\end{tabular}

Selanjutnya dilakukan uji lanjut pasca anava dengan metode Scheffe' untuk mengetahui pengaruh yang signifikan antara ketiga sampel tersebut. Hasil uji komparasi ganda ditunjukkan pada Tabel 5.

Tabel 5. Uji Komparansi Ganda

\begin{tabular}{ccccc}
\hline Komparasi & $\boldsymbol{F}_{\text {hitung }}$ & $\boldsymbol{F}_{\text {tabel }}$ & $\mathbf{A}$ & Keputusan \\
\hline $\boldsymbol{F}_{\mathrm{\mu 1}-\mu 2}$ & 0,184 & & & $H_{0}$ diterima \\
$\boldsymbol{F}_{\mathrm{\mu} 1-\mu 3}$ & 32,531 & 6,20 & 0,05 & $H_{0}$ ditolak \\
$\boldsymbol{F}_{\mathrm{\mu} 2-\mu 3}$ & 92,003 & & & $H_{0}$ ditolak \\
\hline
\end{tabular}

Berdasarkan hasil uji komparansi ganda pada masing-masing model pembelajaran, dengan taraf signifikansi 0,05 diperoleh interpretasi hasil sebagai berikut.

1. Pada $H_{0}: \mu_{1}$ vs $\mu_{2}$ diketahui bahwa $F_{\text {hitung }}=0,184$ dan $F_{\text {tabel }}=6,20$. Berdasarkan perhitungan tersebut terlihat bahwa $F_{\text {hitung }}<F_{\text {tabel }}$. Dengan demikian dapat diambil kesimpulan bahwa $H_{0}$ diterima, artinya tidak terdapat perbedaan yang signifikan antara peserta didik dengan model pembelajaran DMR berbantuan sparkol videoscribe dengan model pembelajan DMR terhadap kemampuan representasi matematis. Berdasarkan Tabel 4 diketahui bahwa rata-rata peserta didik dengan model pembelajaran DMR berbantuan sparkol videoscribe yaitu 73,366 dan peserta didik dengan model pembelajaran DMR yaitu 71,300. Berdasarkan rata-rata tersebut dapat disimpulkan bahwa model pembelajaran DMR berbantuan sparkol videoscribe sama baiknya dengan model pembelajaran DMR terhadap kemampuan representasi matematis. 
2. Pada $H_{0}: \mu_{1} v s \mu_{3}$ diketahui bahwa $F_{\text {hitung }}=32,531$ dan $F_{\text {tabel }}=6,20$. Berdasarkan perhitungan tersebut terlihat bahwa $F_{\text {hitung }}>F_{\text {tabel }}$. Dengan demikian dapat diambil kesimpulan bahwa $H_{0}$ ditolak, artinya terdapat perbedaan yang signifikan antara peserta didik dengan model pembelajaran DMR berbantuan sparkol videoscribe dengan model pembelajan konvensional terhadap kemampuan representasi matematis. Berdasarkan Tabel 4 diketahui bahwa rata-rata peserta didik dengan model pembelajaran DMR berbantuan sparkol videoscribe yaitu 73,366 dan peserta didik dengan model pembelajaran konvensional yaitu 44,733. Berdasarkan rata-rata tersebut dapat disimpulkan bahwa model pembelajaran DMR berbantuan sparkol videoscribe lebih baik dari model pembelajaran konvensional terhadap kemampuan representasi matematis.

3. Pada $H_{0}: \mu_{2}$ vs $\mu_{3}$ diketahui bahwa $F_{\text {hitung }}=92,003$ dan $F_{\text {tabel }}=6,20$. Berdasarkan perhitungan tersebut terlihat bahwa $F_{\text {hitung }}>F_{\text {tabell }}$. Dengan demikian dapat diambil kesimpulan bahwa $H_{0}$ ditolak, artinya terdapat perbedaan yang signifikan antara peserta didik dengan model pembelajaran DMRdengan model pembelajan konvensional terhadap kemampuan representasi matematis. Berdasarkan Tabel 4 diketahui bahwa rata-rata peserta didik dengan model pembelajaran DMR berbantuan sparkol videoscribe yaitu 71,300 dan peserta didik dengan model pembelajaran konvensional yaitu 44,733. Berdasarkan rata-rata tersebut dapat disimpulkan bahwa model pembelajaran DMR lebih baik dari model pembelajaran konvensional terhadap kemampuan representasi matematis.

Hasil pengukuran menunjukkan bahwa penerapan model DMR berbantuan sparkol videoscribe tidak berbeda signifikan terhadap DMR tanpa sparkol videoscribe, namun berbeda signifikan dengan pembelajaran konvensional karena melalui DMR, peserta didik lebih terbantu untuk memahami materi. Hal ini karena peserta didik difasilitasi untuk mencari sumber literatur dalam memecahkan masalahnya secara mandiri. Ini sesuai dengan hasil penelitian Ahmad, Loka, \& Mutiah (2020) dan Domu \& Pesik (2020) dimana DMR efektif dalam pembelajaran karena peserta didik lebih leluasa dalam menggunakan sumber belajar, juga terfasilitasi untuk diskusi dalam kelompok. Namun di sisi lain, penerapan DMR juga menemui kendala, antara lain permesalahan peserta didik yang tidak semuanya aktif dalam pembelajaran, permasalahan peserta didik dalam menyimpulkan, dan menejemen waktu. Hal ini sesuai dengan penelitian Ahmad, Loka, \& Mutiah (2020) yaitu masih ditemukan beberapa peserta didik yang masih belum berpartisipasi dalam proses pembelajaran seperti peserta didik sulit untuk berdiskusi dengan teman kelompok hal ini terlihat dari beberapa peserta didik yang masih bingung saat mengerjakan soal serta peserta didik belum memiliki kemampuan menyimpulkan dengan baik, sehingga masih 
perlu bantuan dari guru. Penelitian Wahyuni, Purwaningsih \& Hadijah (2020) mengungkapkan bahwa selain memiliki banyak kelebihan, DMR juga memiliki beberapa kendala saat diterapkan dalam pembelajaran, yaitu Karena memerlukan persiapan dan tahapan belajar yang sistematis, sehingga waktu yang diperlukan lebih lama namun dari segi kualitas hasil belajar lebih besar pengaruhnya terhadap pemahaman siswa daripada pembelajaran konvensional. Sehingga DMR lebih efektif dalam capaian tujuan pembelajaran jika dibandingkan dengan model pembelajaran konvensional.

\section{SIMPULAN}

Berdasarkan hasil hipotesis dan pembahasan yang telah diuraikan maka dapat disimpulkan bahwa penelitian ini menunjukan adanya pengaruh penggunaan model pembelajaran DMR berbantuan Sparkol Videoscribe terhadap kemampuan representasi matematis peserta didik. Pengaruh yang diperoleh dalam penelitian ini adalah model pembelajaran DMR berbantuan sparkol videoscribe sama baiknya dengan model pembelajaran DMR terhadap kemampuan representasi matematis,model pembelajaran DMR lebih baik dari model pembelajaran konvenional terhadap kemampuan representasi matematis dan model pembelajaran DMR lebih baik dari model pembelajaran konvensional terhadap kemampuan representasi matematis. Kepada pendidik diharapkan model pembelajaran DMR berbantuan sparkol videoscribe dapat dijadikan pertimbangan dalam proses pembelajaran untuk kemampuan representasi matematis dan bagi peneliti semoga apa yang diteliti dapat dilanjutkan oleh peneliti lain dengan penelitian lanjutan dengan penggunaan model matematika yang lebih menarik dan mudah dipahami, dan dalam menyelesaikan soal-soal matematika yang berbeda.

\section{DAFTAR PUSTAKA}

Ahmad, R., Loka, I. N., \& Mutiah, M. 2020. Pengaruh Model Pembelajaran Kooperatif Tipe Diskursus Multi Representasi (DMR) Terhadap Hasil Belajar Siswa Pada Materi Pokok Senyawa Hidrokarbon Kelas Xi Mia Man 1 Mataram. Chemistry Education Practice, 3(1), 41-46.

Anggoro, S., Harmianto, S., \& Yuwono, P. D. 2018. Upaya Meningkatkan Kemampuan Pedagogik Guru Melalui Pelatihan Pembelajaran Tematik Sains Menggunakan Inquiry Learning Process dan Science Activity Based Daily Life. JPPM (Jurnal Pengabdian dan Pemberdayaan Masyarakat), 2(1), 29-35.

Aulia, F., Zulhendra, Z., \& Jaya, P. 2014. Pengaruh Penggunaan Modul pada Model Pembelajaran Kooperatif Tipe Student Team Achievement Divisions terhadap Hasil Belajar Siswa pada Mata Pelajaran Keterampilan Komputer dan Pengelolaan Informasi Di SMK Negeri 2 Bukittinggi. VoteTEKNIKA: Jurnal Vocational Teknik Elektronika dan Informatika, 2(1). 
Bagus, C. 2018. Analisis Kemampuan Representasi Matematis Siswa Dalam Menyelesaikan Soal Lingkaran pada Kelas VII-B MTs Assyafi'iyah Gondang. Suska Journal of Mathematics Education, 4(2), 115-124.

Bani, A. 2016. Pemecahan Masalah dan Representasi Pembelajaran MAtematika. DeltaPi: Jurnal Matematika dan Pendidikan Matematika, 1(2).

Domu, I., \& Pesik, A. 2020. Pengaruh Model Pembelajaran Diskursus Multi Representasi terhadap Hasil Belajar Siswa Materi Himpunan. JSME (Jurnal Sains, Matematika \& Edukasi), 8(2), 122-126.

Effendi, L. A. 2012. Pembelajaran Matematika dengan Metode Penemuan Terbimbing untuk Meningkatkan Kemampuan Representasi dan Pemecahan Masalah Matematis Siswa SMP. Jurnal Penelitian Pendidikan, 13(2), 1-10.

Fitri, N., Munzir, S., \& Duskri, M. 2017. Meningkatkan Kemampuan Representasi Matematis Melalui Penerapan Model Problem Based Learning. Jurnal Didaktik Matematika, 4(1), 59-67.

Fitrianingrum, F., \& Basir, M. A. 2020. Analisis Kemampuan Representasi Matematis Siswa dalam Menyelesaikan Soal Aljabar. VYGOTSKY: Jurnal Pendidikan Matematika dan Matematika, 2(1), 1-11.

Handayani, H. 2015. Pengaruh Pembelajaran Kontekstual Terhadap Kemampuan Pemahaman dan Representasi Matematis Siswa Sekolah Dasar. Didaktik: Jurnal IImiah PGSD STKIP Subang, 1(1), 142-149.

Herman, T., Artinah, T., \& Usdiyana, D. (2017). The Effect of Multirepresentation Discourse Learning on Students Problem Solving Ability. Jurnal Pengajaran MIPA, 22(1).

Hutagaol, K. 2013. Pembelajaran Kontekstual untuk Meningkatkan Kemampuan Representasi Matematis Siswa Sekolah Menengah Pertama. Infinity Journal 2 (1): 85-99.

Lahope, K. S., Tulandi, D. A., \& Mongan, S. W. 2020. Studi Kompetensi Multirepresentasi Mahasiswa pada Topik Interferensi dan Difraksi. Charm Sains: Jurnal Pendidikan Fisika, 1(3), 90-94.

Kristin, F., \& Rahayu, D. 2016. Pengaruh Penerapan Model Pembelajaran Discovery Learning Terhadap Hasil Belajar IPS pada Siswa Kelas 4 SD. Scholaria: Jurnal Pendidikan Dan Kebudayaan, 6(1), 84-92.

Masrifah, M., Setiawan, A., Sinaga, P., \& Setiawan, W. 2019. Investigasi Kemampuan Representasi Grafik Mahasiswa Fisika pada Konsep Hukum Newton.SAINTIFIK@,3(2).

Mulyono, Y. 2018. Critical Thinking Skills of Physics Education Students through CTLBased Fundamental Biology. In Science, Engineering, Education, and Development Studies (SEEDS): Conference Series (Vol. 2, No. 1).

Mulyono, Y. 2018. Improving Creativity of the Future Physics Teachers Through General Biology Learning Based on CTL with Experimental Method. Indonesian Journal of Science and Education, 2(1), 1-7. 
Nadia, L. N., \& Isnarto, I. 2017. Analisis Kemampuan Representasi Matematis Ditinjau dari Self Efficacy Peserta Didik melalui Inductive Discovery Learning. Unnes Journal of Mathematics Education Research, 6(2), 242-250.

Nahdi, S. D. 2017. Implementasi Model Pembelajaran Collaborative Problem Solving untuk Meningkatkan Kemampuan Representasi Matematis Siswa Sekolah Dasar. Jurnal Cakrawala Pendas, 3(1).

Nurfaisah, N. 2018. Efektivitas Penerapan Model Pembelajaran Kooperatif Tipe Diskursus Multy Reprecentation (DMR) Terhadap Kemampuan Pemecahan Masalah Matematika Siswa Kelas VIII SMP Guppi Samata Kabupaten Gowa (Doctoral dissertation, Universitas Islam Negeri Alauddin Makassar).

Nursahara, N. 2017. Pengembangan Perangkat Pembelajaran Berbasis Pendekatan Matematika Realistik Untukmeningkatkan Kemampuan Representasi Matematik dan Self Efficacy Siswa. EKSAKTA: Jurnal Penelitian dan Pembelajaran MIPA, 2(2), 115-121.

Rahmawati, I. 2020. Pengaruh Pembelajaran Inkuiri Model Silver Terhadap Kemampuan Representasi Matematis Siswa SMP. Pasundan Journal of Mathematics Education Jurnal Pendidikan Matematika, 6(2).

Rosita, I \& Leonard. 2015. Meningkatkan Kerja Sama Siswa Melalui Pembelajaran Kooperatif Tipe Think Pair Share. Formatif: Jurnal IImiah Pendidikan MIPA 3 (1).

Rostika, D., \& Junita, H. 2017. Peningkatan Kemampuan Pemecahan Masalah Siswa SD Dalam Pembelajaran Matematika dengan Model Diskursus Multy Representation (DMR). EduHumaniora/ Jurnal Pendidikan Dasar Kampus Cibiru, 9(1), 35-46.

Sabirin, M. 2014. Representasi dalam Pembelajaran Matematika. Jurnal Pendidikan Matematika, 1(2), 33-44.

Sahara, N. 2017. Pengembangan Perangkat Pembelajaran Berbasis Pendekatan Matematika Realistik Untuk Meningkatkan Kemampuan Representasi Matematik dan Self Efficacy Siswa. Jurnal Penelitian Pendidikan MIPA, 2(1), 141-152.

Saputri, L., \& Sari, D. P. 2017. Peningkatan Kemampuan Representasi Matematis Melalui Model Pembelajaran Visualization Auditory Kinesthetic (VAK) Berbantuan Wingeom. Jurnal MathEducation Nusantara, 1(1), 75-83.

Situmorang, M. 2014. Pengembangan Buku Ajar Kimia SMA Melalui Inovasi Pembelajaran Dan Integrasi Pendidikan Karakter Untuk Meningkatkan Hasil Belajar Siswa. Prosiding SEMIRATA 20131 (1).

Subakti, Y. R. 2010. Paradigma Pembelajaran Sejarah Berbasis Konstruktivisme. Jurnal SPPS 24 (1): 31-53.

Sugiana, I. N., Harjono, A., Sahidu, H., \& Gunawan, G. 2017. Pengaruh Model Pembelajaran Generatif Berbantuan Media Laboratorium Virtual terhadap Penguasaan Konsep Fisika Siswa pada Materi Momentum dan Impuls. Jurnal Pendidikan Fisika dan Teknologi, 2(2), 61-65.

Syafri, F. S. 2017. Kemampuan Representasi Matematis dan Kemampuan Pembuktian Matematika. JURNAL e-DuMath, 3(1). 
Tristiyanti, T \& Ekasatya, A. A. 2017. Kemampuan Pemecahan Masalah Matematis Siswa Melalui Model Pembelajaran Kooperatif Tipe Diskursus Multi Representasi dan Reciprocal Learning. JURNAL SILOGISME: Kajian IImu Matematika Dan Pembelajarannya 1 (2): 4-14.

Ulfah, M. 2012. Optimalisasi Hasil Belajar IPA Tentang Sistem Gerak Pada Manusia Melalui Metode Diskusi Dengan Tehnik Pembelajaran Tutor Sebaya. Jurnal Pendidikan Tindakan Kelas 3 (1).

Umar, W. 2012. Membangun Kemampuan Komunikasi Matematis dalam Pembelajaran Matematika. Infinity Journal, 1(1), 1-9.

Wahyuni, A. S., Purwaningsih, N. E., \& Hadijah, I. 2020. Perbedaan Hasil Belajar Siswa Menggunakan Modeldiskursus Multi Representasi dengan Pembelajaran Konvensional. Prosiding Pendidikan Teknik Boga Busana, 15(1).

Yandari, I. A. V., \& Nailah, N. 2019. Penerapan Model Kooperatif Tipe Teams Games Tournament (TGT) untuk Meningkatkan Kemampuan Pemecahan Masalah Matematis Siswa SD. Primary: Jurnal Keilmuan dan Kependidikan Dasar, 11(01), 57-68.

Yekti, S. M. P. 2018. Kemampuan Representasi Matematis Mahasiswa pada Mata Kuliah Pemodelan Matematika Ditinjau dari Prestasi Belajar Program Linier. Journal of Chemical Information and Modeling, 3(2), 1689-1699.

Yuliarti, Y. 2018. Kreativitas Mahasiswa dalam Mengembangkan Paragraf melalui Pembelajaran Bahasa Indonesia dengan Pendekatan PBL. Indonesian Journal of Learning Education and Counseling, 1(1), 42-46.

Zulfikar, R. N. 2019. Pengaruh Pendekatan Metakognitif Terhadap Kemampuan Representasi Siswa Dalam Pembelajaran Matematika SMK Kesehatan Nusantara Kupang. Jurnal Inovasi Matematika, 1(2), 91-98. 